\title{
WYDARZENIA RELIGIJNE W TELEWIZJI POLSKIEJ NA PRZYKLADZIE PROGRAMÓW I TRANSMISJI Z KANONIZACJI JANA PAWLA II I JANA XXIII ORAZ WYBORU PAPIEŻA FRANCISZKA
}

\begin{abstract}
Kanonizacja papieży Jana Pawła II i Jana XXIII oraz wybór papieża Franciszka to jedne z najważniejszych wydarzeń historycznych dla Kościoła katolickiego w ostatnich latach. Dla Telewizji Polskiej były jednymi z najpoważniejszych wyzwań medialnych w historii stacji. Świadczą o tym decyzje kierownictwa Telewizji Publicznej, zaangażowane środki, bogactwo oferty programowej, a także wykorzystanie najnowszych sposobów komunikowania z odbiorcami.

W artykule autor analizuje sposób pokazywania tych wydarzeń w Telewizji Polskiej. Opisuję ofertę programową związaną z tymi wydarzeniami, a także zaangażowane środki do jej realizacji. Przedstawiam również uwarunkowania prawne związane pokazywaniem wydarzeń religijnych $w$ stacjach telewizyjnych. Zdaniem autora Telewizja Polska, pokazując ważne wydarzenia historyczne - kanonizację papieży Jana Pawła II i Jana XXIII, a także wybór papieża Franciszka - nie tylko spełniła zobowiązania wynikające $\mathrm{z}$ istniejących przepisów prawa. Zaprezentowała bogatą ofertę programową skierowaną do różnych grup widzów. Ważną i nowatorską inicjatywą okazał się specjalny kanał internetowy utworzony $\mathrm{w}$ dniach poprzedzających kanonizację, $\mathrm{w}$ którym prezentowano wiele interesujących materiałów archiwalnych. Zaangażowane środki techniczne, układ programu, sposób jego prezentacji i zawartość merytoryczną można przedstawić jako przykład dla innych stacji telewizyjnych w Polsce prezentowania kolejnych ważnych wydarzeń religijnych.

Słowa kluczowe: TVP, kanonizacja, beatyfikacja, Karol Wojtyła, Jan Paweł II, Jan XXIII.
\end{abstract}

\section{DOKUMENTY PRAWNE A RELIGIJNE WYDARZENIA MEDIALNE}

W TVP

Przepisy prawa zobowiązują TVP S.A. (zamiennie nazywaną Telewizją Polską, Telewizją Publiczną lub TVP) do pokazywania treści religijnych, w tym tak zwanych religijnych wydarzeń medialnych. Nawiązując do różnych dyskusji dotyczących mediów publicznych, warto podkreślić, że TVP S.A. musi produkować i emitować programy o treściach religijnych, pokazywać transmisje dotyczące wydarzeń religijnych itd., ponieważ wynika to z przepisów prawa, które nie pozostawiają wątpliwości, co nadawca publiczny może lub powinien czynić w tym zakresie. Takie szczegółowe regulacje nie dotyczą telewizyjnych stacji komercyjnych.

\footnotetext{
1 Mgr Krzysztof Tadej, Interdyscyplinarne Humanistyczne Studia Doktoranckie, Uniwersytet Warszawski, dziennikarz TVP odpowiedzialny za nadzór merytoryczny w programach informacyjnych TVP w czasie kanonizacji Jana Pawła II i Jana XXIII, ul. Woronicza 17, blok F, 00-999 Warszawa, e-mail: ktad@gazeta.pl
} 
Ogólne zapisy dotyczące prezentowania treści religijnych w mediach znajdują się w trzech dokumentach. W „Ustawie o stosunku Państwa do Kościoła Katolickiego w Rzeczpospolitej Polskiej” z 1989 r., która określa prawo Kościoła do emitowania treści religijnych w ,środkach społecznego przekazu”. Stwierdzono, że „Kościół ma prawo do emitowania w środkach społecznego przekazywania Mszy św. w niedzielę i święta oraz swoich programów, w szczególności religijno-moralnych, społecznych i kulturalnych”. Dodano również, że sposób realizacji tych uprawnień reguluje porozumienie między Sekretariatem Episkopatu Polski a jednostkami publicznej radiofonii i telewizji² .

Drugim dokumentem regulującym omawiane kwestie jest „Konkordat między Stolicą Apostolską a Rzeczpospolitą Polską" z 1993 r. Znajdują się w nim gwarancje dla Kościoła katolickiego dotyczące emitowania programów w mediów publicznych. Stwierdzono, że „Kościół Katolicki ma prawo [...] do emitowania programów w publicznej radiofonii i telewizji, na zasadach określonych w prawie polskim ${ }^{3,}$

Trzecim dokumentem, również ogólnie odnoszącym się do prezentowania treści religijnych w mediach, jest „Ustawa z dnia 29 grudnia 1992 r. o radiofonii i telewizji”. Już w art. 1 określa, że ,zadaniem radiofonii i telewizji jest m.in. dostarczanie informacji ${ }^{4}$ ”. Określenie „dostarczanie informacji” interpretowane jest w Telewizji Publicznej jako obowiązek informowania widzów o ważnych wydarzeniach dotyczących polityki, gospodarki, kwestii społecznych i religijnych. Inne przepisy tej ustawy odnoszą się do chrześcijańskiego systemu wartości. W tym dokumencie zapisano na przykład: „Audycje lub inne przekazy powinny szanować przekonania religijne odbiorców, a zwłaszcza chrześcijański system wartości i",

Natomiast dokumentem, w którym znajdują się bardzo szczegółowe zapisy dotyczące treści religijnych w TVP, jest „Umowa między Sekretariatem Episkopatu Polski a Telewizją Polską" zawarta 23 czerwca 1994 r. Umowa ta była już trzykrotnie aktualizowana. Ostatni raz w 2008 r. ${ }^{6}$. Na jej podstawie funkcjonuje w strukturach TVP S.A. Redakcja Audycji Katolickich Telewizji Polskiej. W tym dokumencie znajdują się precyzyjnie ustalone zobowiązania Telewizji Publicznej do transmisji niedzielnej modlitwy Anioł Pański z placu św. Piotra w Watykanie, emisji 45-minutowego programu informacyjno-publicystycznego „w okolicach czasu emisji modlitwy Anioł Pański”, emisji raz w tygodniu 25-minutowego programu dla dzieci i 25-minutowego programu dla młodzieży, a także obowiązek ochrony dziedzictwa Jana Pawła II przez Telewizję Polską. Jeden $z$ punktów umowy dotyczy zobowiązania TVP S.A. do transmisji ważnych wydarzeń religijnych: „Transmisje Mszy Świętych celebrowanych w związku z wydarzeniami ważnymi dla Kościoła w Polsce i na świecie, między innymi: beatyfikacjami, kanonizacjami, pogrzebami osób, które odegrały istotną rolę w życiu wspólnoty Kościoła powszechnego i Kościoła w Polsce, ingresami biskupimi,

\footnotetext{
${ }^{2}$ Ustawa z 17 maja 1989 r. o stosunku Państwa do Kościoła Katolickiego w Rzeczpospolitej Polskiej (Dz.U. 1989 nr 29 poz. 154 ze zm., roz. 8, art. 48, par. 1-2).

${ }^{3}$ Konkordat z 28 lipca 1993 r. między Stolicą Apostolską a Rzeczpospolitą Polską (Dz.U. 1998 nr 51, poz. 318 , art. 20 pkt. 2).

${ }^{4}$ Ustawa z 29 grudnia 1992 r. o radiofonii i telewizji (Dz.U. 1993 nr 7 poz. 34 ze zm., art. 1, pkt. 1).

${ }^{5}$ Ustawa z 29 grudnia 1992 r. o radiofonii i telewizji (Dz.U. 1993 nr 7 poz. 34 ze zm., art. 18, pkt. 2).

http://ekai.pl/wydarzenia/x14283/episkopat-polski-i-tvp-aktualizowaly-umowe-o-wspolpracy/ (dostęp: 20.09.2015).
} 
jubileuszami wydarzeniami ważnymi z punktu widzenia historii Kościoła i Narodu Polskiego",

Zapisy prawne nie mogą określić wszystkiego, co dotyczy prezentowania religijnych wydarzeń medialnych w Telewizji Polskiej, w szczególności do decyzji nadawcy pozostają określenie rodzaju środków technicznych do konkretnych transmisji (co wpływa na jakość przekazu), dobór zespołu dziennikarskiego itd. Od profesjonalizmu i dobrej woli osób podejmujących te decyzje zależy odpowiednie zorganizowanie przekazów medialnych.

\section{KANONIZACJA JANA PAWLA II I JANA XXIII}

Papież Franciszek 5 lipca 2013 r. zatwierdził dekret o cudzie za wstawiennictwem Jana Pawła II i zdecydował, że razem z papieżem Polakiem będzie kanonizowany papież Jan XXIII. Ogłosił również, że data kanonizacji zostanie ogłoszona 30 września 2013 r.

Od tego dnia Telewizja Polska rozpoczęła intensywne przygotowania do obsługi medialnej kanonizacji dwóch papieży. W ciągu następnych 10 miesięcy powstało wiele programów, reportaży i filmów dokumentalnych dotyczących życia, działalności i osiągnięć pontyfikatów obu papieży. Rozwiązywano też wiele skomplikowanych kwestii logistycznych dotyczących specjalnych, wielogodzinnych transmisji z Rzymu i Watykanu, które zaplanowano od 25 kwietnia do 27 kwietnia 2014 r.

\subsection{Założenia programowe dotyczące w związku z kanonizacją Jana Pawła II}

\section{i Jana XXIII w TVP}

W TVP za pokazywanie programów dotyczących kanonizacji, a także transmisje związane z tym wydarzeniem z Rzymu i Watykanu były szczególnie odpowiedzialne osoby kierujące programami informacyjnymi, a także Redakcją Audycji Katolickich.

Osoby odpowiedzialne za decyzje programowe i merytoryczne w programach informacyjnych: Wiadomości i Teleexpress w Programie 1, Panorama w TVP 2, a także w kanale TVP Info podczas spotkań z osobami przygotowującymi i realizującymi programy dotyczące kanonizacji zwracały szczególnie uwagę na:

1. Podkreślanie znaczenia wydarzenia. Kanonizacja dwóch papieży: Jana Pawła II i Jana XXIII podczas spotkań z twórcami programów, filmów, transmisji była określana jako jedno z najważniejszych wydarzeń w Kościele katolickim w XXI w. i wydarzenie wyjątkowe dla milionów Polaków ze względu na ogłoszenie świętym naszego rodaka Jana Pawła II.

2. Przypominanie nauczania Jana Pawła II, czyli pokazywanie fragmentów najważniejszych i najbardziej znaczących przesłań, wypowiedzi, dokumentów papieża. Wyboru tych fragmentów dokonywali dziennikarze przygotowujący programy, często konsultując się z ekspertami zajmującymi się nauczaniem Jana Pawła II.

3. Przedstawienie ważnych faktów $\mathbf{z}$ życia papieża Polaka i najważniejszych dokonań jego pontyfikatu. Zwracanie uwagi, że Jan Paweł II był papieżem całego świata, nie tylko Polski.

\footnotetext{
${ }^{7}$ Porozumienie zmieniające umowę między Sekretariatem Episkopatu Polski a Telewizją Polską, marzec 2008 r. Tekst zapisu na podstawie rozmowy z kierownikiem Redakcji Audycji Katolickich TVP ks. Rafałem Sztejką SJ, maj 2015.
} 
4. Prezentowanie świadectw osób, które poznały Karola Wojtyłę/Jana Pawła II w różnych okresach jego życia.

5. Towarzyszenie Polakom przeżywającym to wydarzenie w różnych miejscach w Polsce i poza jej granicami; prezentowanie ich poglądów i emocji związanych z Janem Pawłem II i kanonizacją.

6. Informowanie o kanonizacji dwóch papieży, przedstawienie w programach również dokonań i życia Jana XXIII, choć od samego początku dla wszystkich ekip redakcyjnych było oczywiste, że większość programów, relacji, rozmów itd. będzie dotyczyła Jana Pawła II.

7. Wyjaśnienie procedur procesów beatyfikacyjnych i kanonizacyjnych, a także pojęcia świętości według Kościoła katolickiego.

Osoby kierujące Redakcją Audycji Katolickich TVP, przekazując zasady programowe, zwracały szczególną uwagę na trzy elementy niezbędne do opowiadania o świętości konkretnych osób ${ }^{8}$. Można je opisać w schemacie: „Ludzie - Bóg - Kościół”. Przekaz medialny polegał na pokazywaniu wypowiedzi osób, które bezpośrednio lub pośrednio $\mathrm{w}$ dniu śmierci Jana Pawła II wyrażały przekonanie „Santo subito” (natychmiast święty). Drugi element związany z Bogiem dotyczył cudownych zdarzeń. Aby uznać kogoś za świętego, potrzebny jest cud zbadany i zatwierdzony przez Kongregację Spraw Świętych w Watykanie (warunek ten nie dotyczy męczenników, którzy zginęli za wiarę). Dlatego Redakcja Audycji Katolickich zleciła realizację programów i filmów o cudownych zdarzeniach i ingerencji Boga w ludzkie życie. Trzeci element związany z Kościołem polegał na informowaniu o etapach procesu kanonizacyjnego i wyjaśnianiu procedur kanonizacyjnych w Kościele katolickim. Przypominano dekret Inter mirifica o środkach społecznego przekazywania myśli. Dokument uchwalony podczas II Soboru Watykańskiego i ogłoszony przez papieża Pawła VI w 1964 r. Zwraca się między innymi uwagę na transmisje katolickie, które - jak podkreślono - „prowadzą słuchaczy i widzów do uczestnictwa w życiu Kościoła i karmią ich prawdami religijnymi" ". Redakcja Audycji Katolickich TVP inicjowała również przedstawianie treści religijnych dotyczących kanonizacji w programach, które nie dotyczyły tej tematyki, na przykład w popularnym serialu Ojciec Mateusz.

\subsection{Oferta programowa TVP w związku z kanonizacją Jana Pawła II i Jana XXIII}

Zarzą TVP przyjął założenie, że kanonizacja w TVP to wydarzenie, dla którego zostanie przygotowana wyjątkowa obsługa medialna. Precyzyjnie zaplanowano bogatą ofertę programową na niemal wszystkich antenach Telewizji Polskiej (takich jak TVP 1, TVP 2, TVP Info, TVP Regionalna, TVP HD, TVP Polonia, TVP Historia, TVP Kultura), a także w 16 ośrodkach regionalnych. Kierownictwo TVP zdecydowało, że programy, filmy, cykle dokumentalne, reportaże dotyczące osób kanonizowanych będą pokazywane z dużą częstotliwością przez miesiąc - od 28 marca 2014 r. - na różnych antenach Telewizji Polskiej. Wśród nich między innymi 30-odcinkowy cykl Metr od świętości, filmy: Cud na Kostaryce, Nasz profesor papieżem, Jan XXIII, Papież nie tylko polski,

\footnotetext{
${ }^{8}$ Rozmowa z kierownikiem Redakcji Audycji Katolickich TVP ks. Rafałem Sztejką SJ, maj 2015.

9 Dekret o środkach społecznego przekazywania myśli. Inter mirifica. Roz II, pkt. 14. http://ekai.pl/biblioteka/dokumenty/x193/dekret-o-srodkach-spolecznego-przekazu-inter-mirifica/ (dostep: 20. 09. 2015)
} 
Pielgrzym milości, Połaczył nas papież, koncerty przygotowane w związku z kanonizacją „Kolory miłosierdzia” w Krakowie Łagiewnikach.

W okresie poprzedzającym kanonizację - od 28 marca do 26 kwietnia 2014 r. - TVP wyemitowała 306 specjalnych programów, reportaży, filmów dokumentalnych (premier i powtórek) dotyczących kanonizacji dwóch papieży. W tym na przykład: Program 1 wyemitował 69 pozycji programowych, Program $2-20$, TVP Polonia - 103, TVP Kultura - 17, TVP Regionalna $-61^{10}$. Informacje dotyczące kanonizacji przekazywano również w stałych programach cyklicznych Redakcji Audycji Katolickich, programach informacyjnych, programach ośrodków regionalnych.

W dniach poprzedzającym kanonizację: 25 i 26 kwietnia 2014 r., a także w dniu kanonizacji Telewizja Polska pokazywała wiele programów specjalnych i transmisji z Rzymu i Watykanu. Wyemitowano specjalne wydania najważniejszych programów informacyjnych, takich jak Wiadomości, Teleexpresu i Panorama.

TVP Info natomiast realizowała na żywo specjalny program z Watykanu, Rzymu i kilku polskich miast przez trzy dni, od piątkowego wieczoru 25 kwietnia do niedzieli 27 kwietnia 2014 r. do godz. 20.00. Program specjalny był realizowany na żywo, przez 24 godziny na dobę, również $\mathrm{w}$ nocy $\mathrm{z}$ soboty na niedzielę. Dotyczył niemal wyłącznie kanonizacji papieży. W nocy, gdy w programach konkurencyjnych stacji pokazywano powtórki wcześniej wyemitowanych programów, dziennikarze TVP przekazywali na żywo rozmowy $\mathrm{z}$ pielgrzymami czekającymi w Watykanie i Rzymie na Mszę św. kanonizacyjną. W ciągu trzech dni w Rzymie i Watykanie wystąpiło na żywo ponad 80 gości, którzy poznali Jana Pawła II w różnych okresach jego życia.

TVP przygotowała również specjalny kanał w internecie: „TVP Regionalna - śladami Jana Pawła II". Dostępny był na tabletach, smartfonach, komputerach osobistych i Platformie Hybrydowej TVP. Od 25 do 28 kwietnia 2014 emitowano tam archiwalne materiały filmowe z papieskich pielgrzymek, a także filmy o Janie Pawle II i Janie XXIII. Jak wynika $\mathrm{z}$ informacji od Joanny Warechy, zastepcy dyrektora ds. Programowych Ośrodka Programów Regionalnych, osoby odpowiedzialnej za treści pokazywane w tym specjalnym kanale, zarejestrowano 51 tys. odtworzeni przez użytkowników i 11 tys. 133 tak zwanych użytkowników unikatowych ${ }^{11}$.

Rok później, z okazji pierwszej rocznicy kanonizacji, Telewizja Polska ponownie uruchomiła specjalny kanał internetowy „Śladami Jana Pawła II”, który był dostępny na stronie internetowej kanału TVP Regionalna, na platformie hybrydowej TVP i w aplikacji TVP Stream ${ }^{12}$. Telewizja Polska również na innych swoich stronach internetowych informowała o wydarzeniach związanych z kanonizacją.

W dniu kanonizacji, 27 kwietnia 2014 r., TVP przygotowała na różnych swoich antenach 45 godzin transmisji z Watykanu związanych w kanonizacją.

Najważniejsze wydarzenie programowe - transmisja Mszy św. - było pokazywane na trzech antenach TVP: w TVP1, TVP Info i TVP Polonia. Za pośrednictwem Telewizji

\footnotetext{
${ }^{10}$ Informacja przekazana przez Biuro Koordynacji Programowej TVP 27 kwietnia 2015 r.

11 Wiadomość wysłana pocztą elektroniczna od Joanny Warechy, zastępcy dyrektora ds. programowych Ośrodka Programów Regionalnych, 13 kwietnia 2015.

http://www.tvp.pl/centrum-informacji/informacje-dla-mediow/komunikaty-centruminformacji/rocznicowy-kanal-internetowy-sladami-jana-pawla-ii/19735212 (dostęp: 20.09.2015).
} 
Polskiej Mszę św. kanonizacyjną obejrzało ponad 8,5 miliona osób - najwięcej z wszystkich stacji telewizyjnych w Polsce.

Sygnał transmisji był bezpłatnie udostępniony przez TVP dla organizatorów zbiorowego oglądania tego wydarzenia, na przykład na rynkach polskich miast, miasteczek i wsi. Telewizja Polska skierowała również na preferencyjnych zasadach możliwość korzystania z programów, reportaży i filmów TVP o Janie Pawle II i Janie XXIII. Oferta została skierowana do różnych instytucji i samorządów, które mogły organizować pokazy po uiszczeniu niewielkiej opłaty.

\subsection{Zaangażowane środki do realizacji obsługi medialnej kanonizacji w TVP}

W związku z kanonizacją do Rzymu i Watykanu przyjechało prawie trzy tysiące dziennikarzy, realizatorów wizji i dźwięku, operatorów z 64 krajów świata. To bardzo duża grupa, choć należy pamiętać, że podczas choroby i w dniu śmierci Jana Pawła II w Biurze Prasowym Watykanu akredytowało się dziewięć tysięcy dziennikarzy z całego świata $^{13}$. W czasie kanonizacji ekipa TVP stanowiła największą grupę osób akredytowanych spoza Włoch. Do ,wiecznego miasta” wysłano 78 osób, w tym 24 dziennikarzy z programów informacyjnych, ośmiu operatorów kamer, pięciu realizatorów wizji i dźwięku, siedem ekip zdjęciowych ${ }^{14}$. To jedna $z$ największych ekip telewizyjnych TVP w Rzymie i Watykanie w historii stacji.

TVP emitowała „wejścia antenowe” na żywo z czterech głównych miejsc: ze specjalnego studia na dachu budynku w pobliżu placu św. Piotra, z dachu klasztoru augustynianów znajdującego się $\mathrm{w}$ pobliżu kolumnady ( $\mathrm{z}$ tego miejsca programy emitowały najsłynniejsze stacje telewizyjne świata), z placu Pio XII i z końca ulicy Conciliazione (głównej ulicy wiodącej do placu św. Piotra). Zastosowano również bezprzewodowe kamery, dzięki którym reporterzy TVP byli obecni w pobliżu placu św. Piotra - tam gdzie znajdowali się polscy pielgrzymi.

\subsection{Analiza programów TVP dotyczących kanonizacji}

Analizując programy TVP dotyczące kanonizacji, należy podkreślić, że była to bardzo bogata oferta programowa skierowana do różnych grup odbiorców. Każda grupa wiekowa mogła znaleźć propozycję skierowaną do siebie. Na przykład dzieci oglądające cykliczny program Ziarno były informowane o zbliżającym się historycznym wydarzeniu.

Dziennikarze realizowali założenia programowe (opisane w rozdziale 1), na przykład wielokrotnie podkreślali wyjątkowość wydarzenia, jakim była kanonizacja. W programach telewizyjnych znajdują się między innymi takie stwierdzenia:

a) „Na całym świecie setki milionów widzów przed telewizorami” (Piotr Kraśko,

Wiadomości - wydanie specjalne);

b) „To jest specjalne wydanie Panoramy” (prezenterka Panoramy);

c) „Jeszcze nigdy dwaj papieże nie byli wynoszeni na ołtarze przez dwóch papieży” (Tomasz Wolny, Panorama, Program 2 TVP);

\footnotetext{
${ }^{13}$ Kanonizacja Jana Pawła II będzie potwierdzeniem tego, czego bytem świadkiem, wywiad o. Stanisława Tasiemskiego z wieloletnim rzecznikiem Stolicy Apostolskiej Jaoquinem NavarroVallsem, Katolicka Agencja Informacyjna, 15 stycznia 2014.

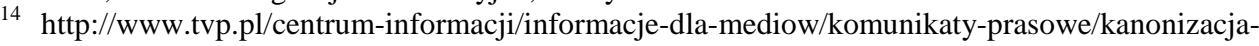
jana-xxiii-i-jana-pawla-ii-w-programach-informacyjnych-tai-tvp/15785935 (dostęp: 20.09.2015).
} 
d) „Dziś dzień, który przejdzie do historii” (Joanna Ladzińska-Molak, Między ziemią a niebem, Program 1 TVP);

e) „Wszyscy mają nadzieję wejść na plac św. Piotra” (Michał Siegieda, Wiadomości wydanie specjalne);

f) „Wszyscy ludzie chwycili się za ręce i rzeczywiście tutaj stało się coś niezwykłego” (Leszek Krawczyk, Wiadomości, Program 1 TVP);

g) „Spełniły się marzenia katolików na całym świecie” (Krzysztof Ziemiec, Wiadomości, Program 1 TVP) ${ }^{15}$.

Podobnie stwierdzenia można odnaleźć $w$ relacjach wielu stacji telewizyjnych na świecie. Dziennikarze włoskiej stacji RAI wielokrotnie podkreślali, że to „kanonizacja stulecia"16, a portugalskie media określiły to wydarzenie jako ,jeden z najważniejszych dni w historii Kościoła katolickiego",17.

Charakterystyczną cechą transmisji TVP z Rzymu i Watykanu było zaangażowanie emocjonalne dziennikarzy. Było to świadome zachowanie omawiane podczas spotkań redakcyjnych przed rozpoczęciem transmisji. Chodziło o przedstawienie wydarzenia jako radosnego święta. Symbolem tych zachowań był taniec dziennikarki TVP Info M. Kwiatkowskiej ${ }^{18}$. Rozpoczęła relację na Piazza Navona, na którym znajdowali się pielgrzymi, przez kilka minut tańczyła z nimi, opowiadając o tym, co się tam dzieje. Innym zjawiskiem było osobiste wspomnienia dziennikarzy - w czasie rozmów ze świadkami życia Jana Pawła II dziennikarze opowiadali również o swoje wspomnienia ze spotkań z papieżem Polakiem.

Analizując programy TVP, należy również zauważyć, że pomijano tematy trudne i kontrowersyjne dotyczące pontyfikatów papieży. W wypadku Jana Pawła II były pokazywane $\mathrm{w}$ minimalnym stopniu lub całkowicie pomijane. Do takich tematów w okresie tego pontyfikatu autor zalicza na przykład niejasne operacje finansowe Banku Watykańskiego, skandale w Kościele katolickim związane z pedofilią, zamordowanie w Watykanie przez jednego z gwardzistów szefa Gwardii Szwajcarskiej i jego żony. Wśród programów, oprócz bezpośrednich transmisji z Rzymu i Watykanu, dominowały świadectwa osób, które znały Jana Pawła II. Na szczególne uwagę zasługują znakomite opowieści fotografa papieża. Arturo Mari w cyklu „Metr od świętości” opowiadał o nieznanych do tej pory zdarzeniach w czasie pontyfikatu Jana XXIII i Jana Pawła II.

Wyjątkowym wydarzeniem programowym była emisja Orędzia papieża Franciszka do Polaków $^{19}$. Zostało ono wyemitowane 26 kwietnia 2014 r. w Programie 1 TVP I

\footnotetext{
15 Połaczyt nas papież, film dokumentalny, reż. Krzysztof Tadej, http://vod.pl/filmydokumentalne/polaczyl-nas-papiez/7tnmyp (dostęp: 20.09.2015).

16 http://wyborcza.pl/1,91446,15866636,Wloskie_media_kanonizacja_stulecia.html (dostęp: 20.09.2015).

http://wyborcza.pl/1,91446,15866779,Portugalskie_media_jeden_z_najwazniejszych_dni_w.html (dostęp: 20.09.2015).

${ }_{18}^{18}$ Połaczyt nas papież...

19 Orędzie papieża Franciszka do rodaków Jana Pawła II, TVP, http://www.tvp.pl/religia/programy-katolickie/papiez-jan-pawel-ii/wideo/kanonizacja/oredziepapieza-franciszka-do-rodakow-jana-pawla-ii/14930265 (dostęp: 20.09.2015).
} 
w Polskim Radiu. Orędzie zostało nagrane po wystosowaniu prośby do papieża Franciszka przez Redakcje Audycji Katolickich Telewizji Polskiej i Polskiego Radia.

\section{WYBÓR PAPIEŻA FRANCISZKA I RELACJA W TVP}

Argentyński kardynał Jorge Mario Bergoglio 13 marca 2013 r. został kolejnym papieżem. To historyczne wydarzenie skupiło uwagę ludzi w wielu krajach. Wybór ten poprzedziła niespodziewana abdykacja papieża Benedykta XVI, który 11 lutego $2013 \mathrm{r}$. ogłosił, że będzie papieżem do 28 lutego 2013 r. do godziny 20.00. Ta decyzja była zaskakująca i wyjątkowa, tym bardziej że ostatnim papieżem, który zrezygnował ze swojego urzędu był Grzegorz XII w 1415 r. Te okoliczności spowodowały ogromne zainteresowanie mediów zarówno abdykacją, jak i wyborem następcy Benedykta XVI.

Przedstawianie wyboru nowego papieża, w porównaniu z kanonizacją Jana Pawła II i Jana XXIII, było o wiele trudniejszym wyzwaniem dla TVP. Osoby decydujące o tzw. ramówce programowej nie mogły $\mathrm{z}$ dużym wyprzedzeniem zaplanować specjalnych programów, reportaży czy filmów dokumentalnych. Podejmowano natychmiastowe decyzje programowe. Tak było od momentu ogłoszenia abdykacji. Stacja TVP Iinfo 11 lutego 2013 r. po godz. 12.00 od razu zaczęła pokazywać komentarze i wypowiedzi ekspertów, a kierownik zespołu Wiadomości Piotr Kraśko natychmiast zdecydował o wylocie do Rzymu, aby relacjonować to wydarzenie. Kilka godzin później dołączył do niego dziennikarz TVP Jacek Tacik, który przez kilka dni przygotowywał materiały filmowe i relacje na żywo dla TVP Info. Kilka dni po abdykacji został zrealizowany film Tajemnica Benedykta XVI, w którym sekretarz papieża w latach 2005-2007 ks. abp Mieczysław Mokrzycki opowiadał o współpracy z Ojcem Świętym, który podjął decyzję o abdykacji.

Analizując programy informacyjne, publicystyczne i katolickie dotyczące wyboru nowego papieża, można zauważyć dwie tendencje. W programach informacyjnych - w Wiadomościach, Panoramie czy Teleexpressie - bardzo często dziennikarze wymieniali nazwiska, jak określają ich watykaniści, tzw. papabili, czyli osób, które mają największe szanse podczas konklawe. Dziennikarze (na przykład Piotr Kraśko w wydaniach specjalnych Wiadomości) często wskazywali na kardynała Scolę jako faworyta w rankingu kandydatów na przyszłego papieża. Oprócz wymieniania nazwisk kandydatów na przyszłego papieża dziennikarze programów informacyjnych TVP relacjonowali wypowiedzi osób oczekujących na wybór następcy św. Piotra, księży, historyków Kościoła, dziennikarzy watykanistów.

Inne założenia programowe można dostrzec w programach Redakcji Audycji Katolickich. Obowiązywała w nich zasada, że nie wymienia się nazwisk kandydatów na nowego papieża i nie spekuluje, kto może zostać wybrany. Kierownik Redakcji Audycji Katolickich ks. Rafał Sztejka SJ stwierdził: „Nie robiliśmy tego, co inne stacje telewizyjne czy inne media. Nie mówiliśmy o tym, kto może być kolejnym papieżem. Kardynałowie wybierają osobę, kierując się zasadą miłości danej osoby do Kościoła i temu, czy konkretna osoba odpowiada aktualnym wyzwaniom, jakie stoją przed Kościołem. Wierzymy, że pomaga im Duch św. Może więc się okazać, że zostanie wybrana inna osoba, niż oczekują lub przewidują dziennikarze" ${ }^{\text {"20 }}$. W programach

\footnotetext{
${ }^{20}$ Rozmowa z kierownikiem Redakcji Audycji Katolickich TVP ks. Rafałem Sztejką SJ, maj 2015.
} 
Redakcji Audycji Katolickich Między ziemia a niebem mówiono o wyzwaniach, jakie stoją przed nowym papieżem, oczekiwaniach ludzi i procedurach wyboru.

Wybór kardynała Bergoglio okazał się zaskoczeniem dla dziennikarzy nie tylko Telewizji Polskiej. Również reporterzy innych stacji, w tym amerykańskich czy angielskich, byli zdziwieni takim wyborem. Jeden $\mathrm{z}$ pielgrzymów w Watykanie obserwujący na żywo pracę dziennikarzy i widząc ogromną nerwowość i zaskoczenie po ogłoszeniu nazwiska nowego papieża, stwierdził: „Dziennikarze przeprowadzili swoje konklawe i wybrali swojego papieża, a kardynałowie swojego". Trudno nie zgodzić się z tym stwierdzeniem, oglądając różne programy telewizyjne dotyczące konklawe.

Koncepcja przekazów medialnych w TVP dotyczących wyboru papieża polegała na ustaleniu, że w momencie pojawienia się „,białego dymu”, czyli znaku o wyborze papieża, nastąpi przerwanie programu w TVP 1 i TVP Info i zostanie wyemitowany specjalny program, który przygotują dwa zespoły: jeden w studiu w Warszawie i drugi w Rzymie. W obu miejscach podczas trwania konklawe były przygotowane zespoły dziennikarzy i na stałe dyżurowali prowadzący i eksperci. W programie tym, oprócz zaproszonych gości i materiałów filmowych, przewidziano oczywiście transmisję dwóch najważniejszych momentów wydarzenia realizowanych przez Telewizją Watykańską (Centro Televisivo Vaticano): ogłoszenie nazwiska nowego papieża i po około 30 minutach pierwsze wystąpienie papieża na balkonie centralnym Bazyliki św. Piotra. Kluczem do sukcesu okazało się doświadczenie dziennikarzy TVP, którzy realizowali wiele programów w Rzymie i Watykanie. Wiedzieli, że wraz z pojawieniem się „białego dymu” nad Kaplicą Sykstyńską w Watykanie zostanie przerwana - ze względów bezpieczeństwa możliwość komunikacji telefonicznej za pomocą telefonów komórkowych. W związku z tym wcześniej zawiadomili pozostałych gości wydania specjalnego programu, którzy wiedzieli, że po pojawieniu się „białego dymu” mają natychmiast przybyć do jednego z dwóch miejsc, z których Telewizja Polska emitowała swój program (specjalne studio na dachu klasztoru Augustynianów znajdujące się bardzo blisko kolumnady placu św. Piotra lub do stanowisk dziennikarskich na placu Pio XII przed placem św. Piotra). Dzięki takiej koncepcji ponad dwugodzinne wydanie specjalne Wiadomości z Watykanu 13 marca 2013 r. wraz komentarzami w warszawskim studiu zostało wyemitowane bez jakichkolwiek zakłóceń. Działo się to w sytuacji, gdy inne stacje telewizyjne (nie tylko polskie) w pospiechu próbowały dodzwonić się do swoich gości i ekspertów, co wówczas było niemożliwe. Dziennikarze TVP w Warszawie podkreślali również, że oprócz precyzyjnego przygotowania różnych wariantów potrzebne jest również szczęście. Jak twierdzą, dzięki temu osobą prowadzącą wydanie specjalne programu w Warszawie w dniu wyboru był ksiądz Andrzej Majewski, jezuita, który od razu mógł opowiedzieć wiele o kardynale Bergoglio, swoim zakonnym współbracie.

\section{PODSUMOWANIE}

Telewizja Polska, pokazując ważne wydarzenia historyczne - kanonizację papieży Jana Pawła II i Jana XXIII, a także wybór papieża Franciszka - nie tylko spełniła zobowiązania wynikające $\mathrm{z}$ istniejących przepisów prawa. Zaprezentowała bogatą ofertę programową skierowaną do różnych grup widzów. Ważną i nowatorską inicjatywą okazał 
się specjalny kanał internetowy utworzony w dniach poprzedzających kanonizację, w którym prezentowano wiele interesujących materiałów archiwalnych. Zaangażowane środki techniczne, układ programu, sposób jego prezentacji i zawartość merytoryczną można przedstawić jako przykład dla innych stacji telewizyjnych w Polsce prezentowania kolejnych ważnych wydarzeń religijnych.

\section{BIBLIOGRAFIA}

[1] Kanonizacja Jana Pawła II będzie potwierdzeniem tego, czego bytem świadkiem, wywiad o. Stanisława Tasiemskiego $\mathrm{z}$ wieloletnim rzecznikiem Stolicy Apostolskiej Jaoquinem Navarro-Vallsem, Katolicka Agencja Informacyjna, 15 stycznia 2014.

[2] Konkordat z 28 lipca 1993 r. między Stolicą Apostolską a Rzeczpospolitą Polską (Dz.U. 1998 nr 51, poz. 318, art. 20 pkt. 2).

[3] Orędzie papieża Franciszka do rodaków Jana Pawła II, TVP, http://www.tvp.pl/religia/programy-katolickie/papiez-jan-pawelii/wideo/kanonizacja/oredzie-papieza-franciszka-do-rodakow-janapawla-ii/14930265 (dostęp: 20.09.2015).

[4] Połaczyt nas papież, film dokumentalny, reż. Krzysztof Tadej, http://vod.pl/filmy-dokumentalne/polaczyl-nas-papiez/7tnmyp (dostęp: 20.09.2015).

[5] Porozumienie zmieniające umowę między Sekretariatem Episkopatu Polski a Telewizją Polską, marzec 2008 r. Tekst zapisu na podstawie rozmowy z kierownikiem Redakcji Audycji Katolickich TVP ks. Rafałem Sztejką SJ, maj 2015.

[6] Rozmowa z kierownikiem Redakcji Audycji Katolickich TVP ks. Rafałem Sztejką SJ, maj 2015.

[7] Rozmowa z kierownikiem Redakcji Audycji Katolickich TVP ks. Rafałem Sztejką SJ, maj 2015.

[8] Ustawa z 17 maja 1989 r. o stosunku Państwa do Kościoła Katolickiego w Rzeczpospolitej Polskiej (Dz.U. 1989 nr 29 poz. 154 ze zm., roz. 8, art. 48, par. 1-2).

[9] Ustawa z 29 grudnia 1992 r. o radiofonii i telewizji (Dz.U. 1993 nr 7 poz. 34 ze zm., art. 1, pkt. 1).

[10]Ustawa z 29 grudnia 1992 r. o radiofonii i telewizji (Dz.U. $1993 \mathrm{nr} 7$ poz. 34 ze zm., art. 18, pkt. 2).

[11]http://ekai.pl/biblioteka/dokumenty/x193/dekret-o-srodkachspolecznego-przekazu-inter-mirifica/ (dostęp: 20. 09. 2015).

[12] http://ekai.pl/wydarzenia/x14283/episkopat-polski-i-tvp-aktualizowalyumowe-o-wspolpracy/ (dostęp: 20.09.2015).

[13]http://www.tvp.pl/centrum-informacji/informacje-dlamediow/komunikaty-centrum-informacji/rocznicowy-kanalinternetowy-sladami-jana-pawla-ii/19735212 (dostęp: 20.09.2015).

[14]http://www.tvp.pl/centrum-informacji/informacje-dlamediow/komunikaty-prasowe/kanonizacja-jana-xxiii-i-jana-pawla-ii-wprogramach-informacyjnych-tai-tvp/15785935 (dostęp: 20.09.2015). 
[15]http://wyborcza.pl/1,91446,15866636,Wloskie_media_kanonizacja_stu lecia.html (dostęp: 20.09.2015).

[16]http://wyborcza.pl/1,91446,15866779,Portugalskie_media_jeden_z_naj wazniejszych_dni_w.html (dostęp: 20.09.2015).

\section{RELIGIOUS EVENTSON TVP (POLISH PUBLIC TELEVISION NETWORK) BASED ON PROGRAMMES AND THE LIVE TRANSMISSION OF THE CANONISATION OF JOHN PAUL II AND JOHN XXIII AND THE CONCLAVE OF 2013 ELECTING POPE FRANCIS}

The article analyses Polish Television's (TVP) reporting of two historical events: the canonisation of Popes John Paul II and John XXIII in 2014 as well as the conclave of 2013 when Francis was elected the Pope. For TVP, both events were some of the most important media challenges in the network's history." During the canonisation services, TVP crews constituted the largest group of people accredited to the event outside Italy. The Eternal City hosted 78 people.

The article examines both the content offer and the network's guidelines. It identifies and studies measures taken to produce all reports, programmes and live transmissions, the use of a web portal specially-designed to present religious content related to the events as well as the legal requirements connected with reporting religious events on TVP. It also includes an outline of the legal background related to showing religious programmes on TVP. The article discusses all regulations stipulated in the Polish law, international agreements as well as the agreement between the Secretariat of Poland's Episcopacy and the Polish Public Television network.

The article analyses TVP programmes related to the canonisation of both popes as well as programmes showing or discussing Cardinal Jorge Mario Bergoglio's selection. In the summary, the author states that "all the technical equipment used, the selection of programmes, the way they were presented, its content can be set as an example for other Polish networks which would like to report important religious events in the future."

Keywords: Polish Public Television Network, TVP, canonisation, beatification, Karol Wojtyla, John Paul II, John XXIII,

DOI:10.7862/rz.2016.hss.34

Przesłano do redakcji: wrzesień 2015

Przyjęto do druku: czerwiec 2016 